\title{
DOMINATION AND
}

\section{CULTURAL RESISTANCE}

Authority and Power

among an Andean People

Roger Neil Rasnake

Duke University Press

Durham and London 1988 
(C) Duke University Press

All rights reserved

Printed in the United States of America

on acid-free paper $\infty$

Library of Congress Cataloging-in-Publication Data

Rasnake, Roger Neil, I95I-

Domination and cultural resistance.

Bibliography: $p$.

Includes index.

I. Quechua Indians-Social life and customs. 2. Quechua Indians-Ethnic identity. 3. Quechua Indians-Grovernment relations. 4. Indians of South America-Bolivia-YuraSocial life and customs. 5. Indians of South AmericaBolivia-Yura-Ethnic identity. 6. Indians of South America-Bolivia-Government relations. 7. Yura (Bolivia)-Social life and customs. I. Title. F2230.2.K4R37 I988 984'.I4 87-35834 ISBN $0-8223-0809-6$ 
for Inge 
